\title{
EVALUATION OF ALOE VERA POTENTIAL AS A SODIUM HYPOCHLORITE SUBSTITUTE FOR WELL-WATER DISINFECTION
}

\author{
1, *AKINBOMI, J.G., ${ }^{2}$ IKHIDE, E.C. \\ ${ }^{1}$ Department of Chemical Engineering, Lagos State University, Epe Campus, \\ julius.akinbomi@lasu.edu.ng; \\ ${ }^{2}$ Centre for Environmental Studies and Sustainable Development, Lagos State University, Ojo Campus,
}

Received: $11^{\text {th }}$ January 2020

Accepted: 21 st June 2020

Published: $20^{\text {th }}$ September 2020

https://doi.org/10.47545/etrj.2020.5.2.063

\begin{abstract}
The need to find alternative water disinfectants without negative consequential health effects is imperative in view of the link that had been established between human consumption of chlorinated water and diseases such as cancer. Therefore, this study was set out to evaluate and compare the water disinfection potential of aloe vera and sodium hypochlorite $(\mathrm{NaOCl})$ in order to determine the suitability of using aloe vera as sodium hypochlorite substitute. The coliform count of the faecal thermo-tolerant coliform (non-Ecoli) isolated from well water sample was 49 $\mathrm{cfu} / 100 \mathrm{ml}$. Disinfectant efficacies of the $\mathrm{NaOCl}$ and Aloe Vera, stored under various conditions, were evaluated and compared using disc diffusion method to determine disinfection susceptibility of the isolated coliform. The two disinfectants showed increase in level of zone of inhibition of the isolated coliforms with increase in disinfectants storage concentration and sun exposure period. As a disinfectant, aloe vera seemed to be more stable when compared with $\mathrm{NaOCl}$ at the storage temperatures of 0,25 and $35^{\circ} \mathrm{C}$. The p-values for using aloe vera and $\mathrm{NaOCl}$ as disinfectants under various conditions of concentration, temperature and sun exposure period ranged between 0.247 and 1.000 indicating non-significant difference when aloe vera was used as sodium hypochlorite substitute.
\end{abstract}

Keywords: Aloe vera, Sodium hypochlorite, Disinfectant substitute, coliforms, Well Water

\section{INTRODUCTION}

Despite the indispensable nature of water to man which is evident in the high percentage of human body water $(67.85 \%)$ [1]; fresh water is often not available in its uncontaminated form for human consumption [2]. A growing number of contaminants including heavy metals, dyes, pharmaceuticals, fluoride, phenols, insecticides, pesticides and detergents, are entering water supplies from industrialization and human activity [3]. Moreover, water borne pathogenic microorganisms, including bacteria, viruses, and parasites like microscopic protozoa and worms, enter waterways through untreated sewage, storm drains, septic tanks, and run off from farms, among others [4]. It is important that effective wastewater treatment is carried out on polluted water to ensure that water that people drink or use domestically is free of germs and toxic chemicals since contaminated water may have adverse effects on human health. Consequently, to obtain water suitable for consumption, contaminated water is usually disinfected using chemicals including chlorine gas $\left(\mathrm{Cl}_{2}\right)$, chloride dioxide $\left(\mathrm{ClO}_{2}\right)$, ozone $\left(\mathrm{O}_{3}\right)$, iodine (I) and potassium permanganate $\left(\mathrm{KMnO}_{4}\right)$, as well as, hypochlorite $\left(\mathrm{OCl}^{-}\right)$such as sodium hypochlorite $(\mathrm{NaOCl})$, chloramines $\left(\mathrm{NH}_{2} \mathrm{Cl}\right)$, calcium hypochlorite $\left(\mathrm{Ca}(\mathrm{OCl})_{2}\right)$, lithium hypochlorite $(\mathrm{LiOCl})[5,6]$. The efficacy of any water treatment method is affected by a number of factors, including microbial load, disinfectant strength/concentration, and microbial contact time with disinfectants, temperature and $\mathrm{pH}$ of the disinfection process, among others [5].

Although most of the reagents used in water disinfection are effective and have residual effect benefit; there are health challenges with usage of the reagents for water disinfection including forming of carcinogenic disinfection by-products (DBPs). Various research works had established the link between human consumption of chlorinated water and diseases such as cancer, birth defects, arteriosclerosis, immunity deficiency, among others [7-16]. Chemical disinfection of water using sodium hypochlorite $(\mathrm{NaOCl})$ has some challenges with the formation of harmful disinfection by-products from its reaction with organic materials in water. Besides, sodium hypochlorite is unstable and may disintegrate when stored at higher concentrations, lower $\mathrm{pH}$, higher temperature, and where it is exposed to sunlight [17]. The challenges, if unresolved, can affect the effectiveness of the disinfection process 
of water which, as a consequent, can affect the process economy and the quality of the treated water, as well as the healthiness of people. Hence, there is a need to seek for benign alternatives that could be used in place of chlorine for water disinfection.

Meanwhile, plants are known to possess various secondary metabolites with profound antimicrobial properties but minimal side effects when compared with side effects from chemical disinfectants. Hence, they have been used extensively as disinfectant agents in traditional medicines for many years. The most commonly used herbs with disinfectant properties are Azdirachta indica, Eucalyptus robusta, Aloe barbadensis, Aloevera, Withaniasomniferum, Andrographispaniculata, Aeglemarmelos, Berberisvulgaris, Cinnamomumverum, Piper nigrum, Rhamnuspurshiana, Capsicum annuum, Syzygiumaromaticum, Eucalyptus globulus, Gaultheria procumbens, Cassia angustifolia, Cassiafistula, Menthapiperita, among others [18-20]. Aloe vera antimicrobial effect is due to its main gel components including anthraquinones, phenols and terpenoids, which target mostly the bacterial cell wall and membrane. Because of the ability of aloe vera to synthesize aromatic substances that are effective against viruses, bacteria, and fungi, many proposals have been made regarding the use of aloe vera as a substitute for chemical disinfectants [21-25]. However, the effectiveness of aloe vera and other plants for their antimicrobial effects is subjected to a number of factors such as temperature, $\mathrm{pH}$ and organic matter, among others [26, 27]. Various studies have been done as regards the effectiveness of different disinfectants to completely destroy pathogens during water treatment processes; however, there are still research gaps to be investigated. Limited data are available on the suitability of using aloe vera as a substitute for $\mathrm{NaOCl}$ for water disinfection.

The main aim of the study is, therefore, to compare the antimicrobial effects of sodium hypochlorite and aloe vera gel, stored under various conditions, for the purpose of controlling microbial contamination of well-water samples. The effects of storing aloe vera gel and sodium hypochlorite disinfectants at various conditions (concentrations, temperature and sun exposure period) on the effectiveness of well water disinfection would be investigated. Consequently, the suitability of aloe vera to be used as a substitute for sodium hypochlorite disinfectant would be determined. Application of aloe vera gel for water disinfection might help in the effort to overcome the challenges posed by $\mathrm{NaOCl}$ when used as disinfectant.

\section{MATERIALS AND METHODS}

\subsection{Preparation for microbiological analysis of well water}

The materials used during the research work were sample bottles with stoppers/caps, aluminium foil, autoclave, distilled water, gas burner, alcohol solution, tryptone water, $1 \mathrm{~g} / \mathrm{L}$ sodium thiosulphatepentahydrate $\left(\mathrm{Na}_{2} \mathrm{~S}_{2} \mathrm{O}_{3} \cdot 5 \mathrm{H}_{2} \mathrm{O}\right)$, sodium hypochlorite and aloe vera gel solutions, heating mantle, magnetic stirrer, chemical balance, pipettes: $(0.1-1 \mathrm{ml}$ and $10 \mathrm{ml})$, autoclave, incubator(s) or water-baths, gas burner and fire extinguisher. Other experimental materials include culture media including Mac Conkey broth (Purple), Kovacs reagent and Mac Conkey Sorbitol Agar Base, as well as, media preparation equipment such as culture tubes containing inverted vials (Durham tubes), Inoculation loop and holder. Water samples were drawn from the well water located at Isheri-Osun in Isolo Local Government Area, Lagos with a geographical location of $6.53872 \mathrm{~N}$ and $3.25131 \mathrm{E}$.

Prior to the preparation for microbiological analysis of well water, the physical parameters including colour and turbidity of the well water were determined. Following the determination of the physical parameters of the well water, the sample bottles were washed thoroughly and rinsed with distilled water. Screw bottle caps were loosely fastened to the sample bottles prior to sterilization in an autoclave. A strip of aluminium foil was placed inside the neck of each sample bottle to prevent the stopper/cap from getting stuck during sterilization. The stopper was used to protect the sample bottles from contamination. The steam sterilization of the bottles was done at $120^{\circ} \mathrm{C}$ for 20 minutes. After the sterilization, the bottles were allowed to cool before they were tightened using the stoppers and then stored in a refrigerator until required. The sample water was drawn from a tap connected to a well that was fitted with a pump. To draw sample water from the well, the hands were washed and then the tap was cleaned. The hands were washed again before opening the tap. The tap was then opened until it reached its maximum rate of flow. The water was allowed to flow from the tap for 1 to 2 minutes to clear the service line. The tap was then closed and the tap spout/nozzle was sterilized using a flame since the spout was made of iron.

After the spout was sterilized, the tap was opened again to allow the water to flow for 1 to 2 minutes at normal rate. The sterilized bottle was then opened carefully (while keeping the fingers on the aluminum foil) and immediately put under the water jet for the bottle to be filled to the shoulder with approximate volume of $100 \mathrm{~mL}$ of the well water. After filling the sample bottle to the shoulder, five drops of aqueous $1 \mathrm{~g} / \mathrm{L}$ of sodium thiosulphate $\left(\mathrm{Na}_{2} \mathrm{~S}_{2} \mathrm{O}_{3} \cdot 5 \mathrm{H}_{2} \mathrm{O}\right)$ were added to neutralize any residual chlorine which could distort the results of the analyzed 
sample. The tap was turned off and stopper/cap, along with the aluminum foil, was used to tighten the sample bottle. The bottle was then gently shaken to allow uniform mixing of the content. A label, containing the location, the time of sampling, the date and the sampler's name, was attached to the sample bottle. The sample bottles were stored in melted ice/refrigerator and transported to the laboratory for analysis to be carried out within two hours [28].

Two disinfectants including sodium hypochlorite and aloe vera gel, were prepared for the well water disinfection. About 5\% sodium hypochlorite was obtained from the market and diluted to obtain more concentrations $(1,2,3$, and 4\%). The different concentrations were stored under different conditions. Regarding Aloe Vera, full grown plants were obtained and cut open to extract the gel from the plant. About $5 \mathrm{~g}$ of the extracted gel was then dissolved in $95 \mathrm{~g}$ of distilled water to obtain 5\% Aloe Vera solution from which several dilutions were made to obtain four other concentrations $(1,2,3$, and $4 \%)$.

\subsection{Microbiological analysis of well water}

Most probable number (MPN) was the microbiological analysis that was used in this research work. Most Probable Number (MPN) is a method used to estimate the concentration of viable microorganisms in a water sample by replicating liquid broth growth in ten-fold dilutions [29-32]. Presumptive test was used for the detection and estimation of total coliform organisms; the Gram-negative bacteria that ferment lactose at $35-37^{\circ} \mathrm{C}$ within $24-48$ $\mathrm{h}$, in the well water sample. MacConkey broth that contained indicator bromocresol purple was the culture medium used for the presumptive detection and isolation of coliform organisms in the water samples. The medium formula in one litre of distilled water consisted of peptone $(20 \mathrm{~g})$, lactose $(10 \mathrm{~g})$, bile salts $(5 \mathrm{~g})$, sodium chloride $(5 \mathrm{~g})$ and bromocresol purple $(0.01 \mathrm{~g})$. The medium was maintained at $\mathrm{pH}$ of 7.4 and temperature of $25^{\circ} \mathrm{C}$.

To carry out the presumptive test, MacConkey broth with indicator bromocresol purple was prepared in single $(40 \mathrm{~g} / \mathrm{l})$ and double $(80 \mathrm{~g} / \mathrm{l})$ strength concentration. The prepared broth medium was autoclaved at $121^{\circ} \mathrm{C}$ for 15 minutes and later put in the three rows of five tubes each that were arranged in a test-tube rack. The tubes in the first row contained $10 \mathrm{ml}$ of double-strength (concentration) MacConkey broth while the tubes in the second and third rows contained $10 \mathrm{ml}$ of single-strength MacConkey broth. With a sterile pipette, $10 \mathrm{ml}$ of the $100 \mathrm{ml}$ of water sample was added to each of the five tubes in the first row which contained double-strength presumptive medium. To each of the five tubes in the second row which contained single-strength presumptive medium, $1 \mathrm{ml}$ of the $100 \mathrm{ml}$ of the water sample was added using the sterile pipette. Regarding the five tubes in the third row which contained single-strength presumptive medium, $0.1 \mathrm{ml}$ of the water sample was added. After gently shaking the tubes to mix the contents, the 15 test tubes were incubated at $35^{\circ} \mathrm{C}$ for $24-48$ hours. At the end of the 48 -hour incubation period, each test tube was gently shaken to observe acid formation and gas effervescence in the tubes. Acid formation was indicated by a yellow colouration of the broth. The tubes with gas effervescence and yellow colouration of the broth were considered positive. The number of positive tubes after 48 hours was recorded. Gas production and yellow colouration of the broth at the end of 24-48 hours' incubation were presumed to be due to the presence of coliforms in the sample.

The number of total coliforms in the well water after the presumptive test was determined by counting the number of tubes giving positive reaction (i.e. both color change and gas production) and comparing the pattern of positive results (the number of tubes showing growth at each dilution) with standard statistical tables. From the number of tubes showing the presence of acid and gas, the most probable number of (presumed) coliform bacteria present in $100 \mathrm{ml}$ of the original water was estimated by reference to standard statistical tables. The results were reported as CFU/ $100 \mathrm{~mL}$ Confirmatory test was done in order to confirm the presence of faecal thermo-tolerant coliforms (E.coli)that ferment lactose at $44-45^{\circ} \mathrm{C}$. To confirm the presence of faecal thermo-tolerant coliforms (E.coli), two drops from each presumptive positive tube were transferred into five tubes containing $3 \mathrm{ml}$ of tryptone water using a sterile loop. The five test tubes with the media were then incubated at $\left(44-45^{\circ} \mathrm{C}\right)$ for 24 hours. After incubation, $0.1 \mathrm{~mL}$ of Kovacs reagent (a mixture of paradimethyl amino bezaldehyde, Isoamyl alcohol and sulphuric acid) was added into each of the five test tubes containing the media and the tryptone water. The test tubes were then mixed gently. On observation, indole growth (presence of a red colour in the Kovacs reagent that forms a film over the aqueous phase of the medium) was absent indicating that faecal thermo-tolerant coliforms (E.coli) were absent. This showed that the well water samples contained faecal thermo-tolerant coliforms that were not E.coli.

\subsection{Antimicrobial Sensitivity of the isolated microorganisms to Sodium hypochlorite and Aloe Vera Disinfection}

Disinfection effectiveness of $\mathrm{NaOCl}$ and Aloe Vera solutions, stored under various conditions, was evaluated and compared using disc diffusion agar method [33-35]. The method was used to determine the effectiveness of the 
two disinfectants ( $\mathrm{NaOCl}$ and Aloe Vera solutions), as well as, disinfection susceptibility of the isolated coliforms from the well water samples. Sterilized nutrient agar medium plates were seeded with isolated coliform from the well water samples to grow bacterial colonies. The disks containing the disinfectants were then placed on top of the agar plate. The plates were incubated at $37 \pm 1^{\circ} \mathrm{C}$ for $24 \mathrm{~h}$ to see the effect of disinfectants $(\mathrm{NaOCl}$ and $\mathrm{Aloe}$ vera) under various conditions (concentration, storage temperature, sun exposure period) on the isolated microbial growth. The zone of growth inhibition, which was a circular region around the spot of the disinfectant in which the isolated bacteria colonies did not grow, was used to measure the susceptibility of the isolated coliform towards the disinfectants. The diameter of the zone was related to the susceptibility of the isolate coliform. The zones of growth inhibition around each of the antibiotic disks were measured to the nearest millimeter.

\section{RESULTS AND DISCUSSIONS}

The microbial assessment tests (presumptive and confirmatory tests) carried out on the water samples from the well water indicated the presence of thermo-tolerant non E. coli Coliform only, with the coliform count of 49 CFU/100ml (Table 1). Previous studies also confirmed contamination of well water with one or more bacterial pathogens $[36,37]$. The study on the zone of growth inhibition was intended to determine the effectiveness of the two disinfectants including $\mathrm{NaOCl}$ and Aloe Vera solutions on the isolated coliform from the well water samples. The results of the confirmatory test carried out showed that the coliforms present in the well water sample are non- $E$ coli thermo-tolerant coliform. As shown in Table 2, the comparison of the efficacy of $\mathrm{NaOCl}$ and aloe vera gel as disinfectants on the isolates show that faecal thermo-tolerant coliform from the well water were inhibited at the highest zone of inhibition of $6 \mathrm{~mm}$ by $5 \% \mathrm{NaOCl}$ concentration, $5 \mathrm{~mm}$ at $35^{\circ} \mathrm{C}$ and $12 \mathrm{~mm}$ at $10 \mathrm{hr}$ sunlight exposure of $\mathrm{NaOCl}$. The aloe vera highest disinfectant efficacy on the faecal thermo-tolerant coliform from the well water shows $5 \mathrm{~mm}$ zone of inhibition at $5 \%$ concentration, $6 \mathrm{~mm}$ at 0,25 and $35^{\circ} \mathrm{C}$ and $5 \mathrm{~mm}$ at zero sunlight exposure time.

Table 1: Physical parameters and microbiological analysis of well water samples

\begin{tabular}{|c|c|c|c|c|c|}
\hline $\mathrm{S} / \mathrm{N}$ & Parameters & & & Present Study & WHO Standard [30] \\
\hline \multirow[t]{2}{*}{1} & \multirow{6}{*}{$\begin{array}{l}\text { Physical } \\
\text { property } \\
\text { Microbiological } \\
\text { analysis }\end{array}$} & \multicolumn{2}{|l|}{ Colour } & Colourless & Colourless \\
\hline & & \multicolumn{2}{|l|}{ Turbidity (NTU) } & 12 & 25 \\
\hline \multirow[t]{4}{*}{2} & & \multirow{3}{*}{$\begin{array}{l}\text { Number of } \\
\text { positive tubes } \\
\text { after } 48 \text { hours }\end{array}$} & 10ml-tube & 5 & - \\
\hline & & & 1ml-tube & 2 & - \\
\hline & & & $0.1 \mathrm{ml}$-tube & 0 & - \\
\hline & & $\begin{array}{l}\text { Coliform count } \\
\text { (CFU/100ml) }\end{array}$ & & 49 & 0 \\
\hline
\end{tabular}

WHO - World Health Organization

Statistical analyses of the results were done to determine if there were significant difference between the disinfection effectiveness of aloe vera and $\mathrm{NaOCl}$, against the Faecal Thermo tolerant Coliform non-Ecoli) isolated from the well water samples. As given in Table 2, the p-values obtained when the effectiveness values (indicated by the zone of inhibition) of the two disinfectants (aloe vera and $\mathrm{NaOCl}$ ) were analyzed using the Minitab paired t-test, were 1.000, 0.468 and 0.247 ; for storage concentration, storage temperature and sun exposure period of the disinfectants, respectively. All the p-values were greater than the criterion p-value which was chosen as $\alpha$-level $=0.05$ which indicates that there was no statistical difference in the dissection efficacies of aloe vera and $\mathrm{NaOCl}$ under the various experimental conditions investigated. In other words, the difference was not statistically significant, and as such, aloe vera can be used as a sodium hypochlorite substitute for well water disinfection without reducing the expected disinfection efficacy.

\section{CONCLUSION}

This study was set out to evaluate and compare the antimicrobial effects of sodium hypochlorite and aloe vera gel, stored under various conditions and parameters; on coliform isolates from well-water samples. The well water samples collected were subjected to presumptive and confirmatory tests which showed that the well water contained faecal thermo-tolerant coliform (non-Ecoli). The disinfectant efficacy of the $\mathrm{NaOCl}$ and Aloe vera was evaluated and compared on the isolated coliform from the well-water samples using the disc diffusion method with various condition and parameters for the two disinfectants. The results showed that sodium hypochlorite $(\mathrm{NaOCl})$ and aloe vera were effective disinfectants against coliform isolated from the water samples as indicated by the different values of zones of inhibition of the isolated coliform. The $p$-values further showed that that there 
were no statistical difference in the disinfection efficacies of aloe vera and $\mathrm{NaOCl}$ under the various experimental conditions investigated. This means that aloe vera can be used as a substitute for sodium hypochlorite during disinfection process of well-water without reducing the expected disinfection efficacy. Application of aloe vera gel for water disinfection might also help to overcome challenges that occur when $\mathrm{NaOCl}$ is used as disinfectant.

Table 2: Antimicrobial Sensitivity of the isolated Faecal Thermo-tolerant Coliform (non-Ecoli) to Sodium hypochlorite and Aloe Vera Disinfection

\begin{tabular}{|c|c|c|c|c|c|}
\hline $\mathrm{S} / \mathrm{N}$ & $\begin{array}{l}\text { Disinfectant } \\
\text { Treatment }\end{array}$ & Parameters & $\begin{array}{l}\text { Zone of growth } \\
\text { inhibition of FTC by } \\
\mathrm{NaOCl} \text { disinfectant }\end{array}$ & $\begin{array}{l}\text { Zone of growth } \\
\text { inhibition of FTC by } \\
\text { Aloe vera disinfectant }\end{array}$ & P-values \\
\hline \multirow[t]{5}{*}{1} & Storage & $1 \%$ & 1 & 3 & \multirow{5}{*}{1.000} \\
\hline & \multirow{4}{*}{$\begin{array}{l}\text { Concentration } \\
(\%)\end{array}$} & $2 \%$ & 4 & 3 & \\
\hline & & $3 \%$ & 2 & 3 & \\
\hline & & $4 \%$ & 5 & 4 & \\
\hline & & $5 \%$ & 6 & 5 & \\
\hline \multirow[t]{5}{*}{2} & \multirow{5}{*}{$\begin{array}{l}\text { Storage } \\
\text { Temperature } \\
\left({ }^{\circ} \mathrm{C}\right)\end{array}$} & 0 & 4 & 6 & \multirow[t]{5}{*}{0.468} \\
\hline & & 25 & 4 & 6 & \\
\hline & & 35 & 5 & 6 & \\
\hline & & 45 & 1 & 1 & \\
\hline & & 55 & 2 & 0 & \\
\hline \multirow[t]{5}{*}{3} & \multirow{5}{*}{$\begin{array}{l}\text { Exposure period } \\
\text { to sunlight (hr) }\end{array}$} & 0 & 1 & 5 & \multirow[t]{5}{*}{0.247} \\
\hline & & 4 & 3 & 0 & \\
\hline & & 6 & 4 & 1 & \\
\hline & & 8 & 5 & 2 & \\
\hline & & 10 & 12 & 2 & \\
\hline
\end{tabular}

FTC: Faecal Thermo-tolerant Coliform(non-Ecoli)

\section{ACKNOWLEDGEMENT}

The authors express their gratitude to Lagos State University management for their support during the research project.

\section{REFERENCE}

1. H.H. Mitchell, T.S. Hamilton, F.R. SteggerdaH.W. Bean, "The chemical composition of the adult human body and its bearing on the biochemistry of growth". J . Biol. Chem., Vol 168, No3, 625-637.

2. C.J. Vörösmarty, P.B. McIntyre, M.O. Gessner, D. Dudgeon, A.A. Prusevich, P. Green, S. Glidden, S.E. Burn, C. Sullivan, C.R. Liermann, P.M. Davies, "Global threats to human water security and river biodiversity”. Nature, Vol 467, No 7315, 2010, 555-561.

3. R.P. Schwarzenbach, B.I. Escher, K. Fenner, T.B. Hofstetter, C.A. Johnson, U. von-Gunten, and B. Wehrli, "The challenge of micropollutants in aquatic systems". Science, Vol 313, No 5790, 2006, 1072-1077

4. F.D. Daschner, H. Rüden, R. Simon, "Microbiological contamination of drinking water in a commercial household water filter system”. Eur. J. Clin. Microbiol. Infect. Dis., Vol 15, 1996, 233-237.

5. F. Zanetti, G. de-Luca, P. Tarlazzi, S. Stampi, "Decontamination of dental unit water systems with hydrogen peroxide". Letters in Applied Microbiology, Vol 37, No 3, 2003, 201-206.

6. C. Estrela, C.R.A. Estrela, E.L. Barbin, J.C.E. Spanó, M.A. Marchesan, J.D. Pécora, "Mechanism of Action of Sodium Hypochlorite”. Braz Dent J, Vol 13, No 2, 2002. 113-117.

7. I.H. Mohsen, A.H. Mohsen, H.K. Zaidan, "Health Effects of Chlorinated Water: a Review Article".Pak. J. Biotechnol., Vol 16, No 3, 2019, 163-167.

8. A. Bernard, "Chlorination products: emerging links with allergic diseases". Curr. Med. Chem., Vol 14, No 16, 2007, 1771-1782. 
9. A. Florentin, A. Hautemanière, P. Hartemann, "Health effects of disinfection by-products in chlorinated swimming pools". Int J Hyg Environ Health, Vol 214, No 6, 2011, 461-469.

10. A. Bernard, S. Carbonnelle, C. de-Burbure, O. Michel, M. Nickmilder, "Chlorinated pool attendance, atopy, and the risk of asthma during childhood". Environmental Health Perspectives, Vol 114, No 10, 2006, 15671573.

11. V. Bougault, J. Turmel, B. Levesque, L.P. Boulet, “The respiratory health of swimmers".Sports Medicine, Vol 39, No 4, 2009, 295-312.

12. B.F. Hwang and J.J. Jaakkola, "Water chlorination and birth defects: a systematic review and meta-analysis". Arch Environ Health, Vol 58, No 2, 2003, 83-91.

13. D.S. Michaud, M. Kogevinas, K.P. Cantor, C.M. Villanueva, R. Garcia-Closas, A. Tardon, A. Carrato, M. Dosemeci, D.T. Silverman, "Total fluid and water consumption and the joint effect of exposure to disinfection by-products on risk of bladder cancer". Environ Health Perspect, Vol 115, No 11, 2007, 15691572 .

14. B. Nemery, P.H.M. Hoet, D. Nowak, "Indoor swimming pools, water chlorination and respiratory health". European Respiratory Journal, Vol 19, No 5, 2002, 790-793.

15. M.J. Nieuwenhuijsen, Toledano, M.B., J. Bennett, N. Best, P. Hambly, C. de-Hoogh, D. Wellesley, P.A. Boyd, L. Abramsky, N. Dattani, J. Fawell, D. Briggs, L. Jarup, P. Elliott, "Chlorination disinfection byproducts and risk of congenital anomalies in England and Wales". Environ Health Perspect Environmental Health Perspectives, Vol 116, No 2, 2008, 216-222.

16. C.P. Weisel, S.D. Richardson, B. Nemery, G. Aggazzoti, E. Baraldi, E.R. Blatchley, B.C. Blount, K.H. Carlsen, P.A. Eggleston, F.H. Frimmel, M. Goodman, G. Gordon, S.A. Grinshpun, D. Heederik, M. Kogevinas, J.S. LaKind, M.J. Nieuwenhuijsen, F.C. Piper, S.A. Sattar, "Childhood asthma and environmental exposures at swimming pools: state of the science and research recommendations". Environ Health Perspect., Vol 117, No 4, 2009, 500-507.

17. Montgomery, J.M. Water Treatment Principles and Design. 1st ed. John Wiley \& Sons; 1985.

18. D.P. West, Y.F. Zhu, "Evaluation of aloe vera gel gloves in the treatment of dry skin associated with occupational exposure. Am J Infect Control., Vol 31, No 8, 2003, 40-42.

19. A. Karnwal, A. Dohroo, M.A. Mannan, "Microbial analysis of potable water and its management through useful plant extracts". International Journal of Sciences and Research, Vol 73, No 3, 2017, 44-49.

20. J. Heggers, A. Kucukcelebi, D. Listengraten, J. Stabenau, F. Ko, L.D. Broemeling, M.C. Robson, W.D. Winters, "Beneficial effect of aloe on wound healing in an excisional wound model". J. Altern Complement Med., Vol 2, No 2, 1996, 271-277.

21. A. Bhardwaj, S. Ballal, N. Velmurugan, "Comparative evaluation of the antimicrobial activity of natural extracts of Morinda citrifolia, papain and aloe vera (all in gel formulation), $2 \%$ chlorhexidine gel and calcium hydroxide, against Enterococcus faecalis: An in vitro study”. J Conserv Dent. , Vol 15, No 3, 2012, 293-297.

22. R. Lawrence, P. Tripathi, E. Jeyakumar, Isolation, Purification and Evaluation of Antibacterial Agents from Aloe Vera. Braz. J. Microbiol., Vol 40, No 4, 2009., 906-915.

23. S. Pareek, A. Nagaraj, P. Sharma, M. Atri, S. Walia, S. Naidu, A. Yousuf, "Disinfection of Dental Unit Water Line Using Aloe Vera: In Vitro Study”. International Journal of Dentistry, Vol 2013, No 618962, 2013.

24. A. Dohroo, A. Karnwal, M. Ghai, "Recent developments in Neem (Azadirachta indica - A. Juss) derived antimicrobial constituents for control of human and plant diseases - a review". Ann. Acad.Med. Siles, Vol 70, 2016, 220-223. 
25. M.D. Boudreau, F.A. Beland, "An evaluation of the biological and toxicological properties of Aloe Barbadensis (Miller), Aloe vera. J. Environ. Sci. Health C, Vol 24, No 1, 2006, 103-154.

26. B.J. Juven, J. Kanner, F. Schved, H. Weisslowicz, "Factors that interact with the antibacterial action of thyme essential oil and its active constituents. J Appl Bacteriol., Vol 76, No 6, 1994, 626-631.

27. S.A.F. Kusuma, D. Yusuf, and A. Baitariza, "The effect of different storage temperatures on antiseptic gel stability containing green tea extract formulated with Aloe Vera gel". International Journal of Applied Pharmaceutics, Vol 11, No 4, 2019, 224-229.

28. Y. Madrid and Z.P. Zayas, "Water sampling: traditional methods and new approaches in water sampling strategy". Trends in Analytical Chemistry, Vol 26, No 4, 2007, 293-299.

29. Cappuccino, J.G., Sherman, N. Microbiology:A Laboratory Manual. 8thed. San Francisco, CA, USA: Pearson Benjamin Cummings; 2008,

30. WHO, World Health Organization: Guidelines for drinking-water quality, Surveillance and Control of Community Supplies. 2nd ed. Vol. 3, No. 4-16, Switzeiland;1999.

31. WHO, World Health Organization: Guidelines for Drinking Water Quality. 3rd ed. Vol.1. Switzerland; 2009.

32. N.R. Ngwa, N. Chrysanthus, "Bacteriological analysis of well water sources in the Bambui student residential area”. Journal of Water Resource and Protection, Vol 5, No 11, 2013, 1013 - 1017.

33. A. Dohroo, A. Karnwal, M. Ghai, "Recent developments in Neem (Azadirachta indica - A. Juss) derived antimicrobial constituents for control of human and plant diseases - a review". Ann. Acad.Med. Siles., Vol $70,2016,220-223$.

34. B.L. Reller, M. Weinstein, J.H. Jorgensen, and M.J. Ferraro, “Antimicrobial Susceptibility Testing: A Review of General Principles and Contemporary Practices”. Clinical Infectious Diseases, Vol 49, No 11, 2009, 17491755 .

35. A.W. Bauer, W. Kirby, M,M., J.C. Sherris, M. Turk, “Antibiotic susceptibility testing by a standardised single disk method". Am J Cin Pathol, Vol 45, 1966, 493-496.

36. N.J. Amaeze, A.A. Irekeola, "Determination of Coliforms in Different Sources of Drinking Water in Gwagwalada, Abuja". Report and Opinion, Vol 7, No 1, 2015, 1-6.

37. K.O. Akinyemi, A.O.B. Oyefolu, O.B. Salu, O.A. Adewale, A.K. Fasure,"Bacterial Pathogens Associated with Tap and Well Waters in Lagos.Nigeria”. East and Central African Journal of Surgery, Vol 11, No 1, 2006, 110-117. 